\title{
TRADITIONAL HERBAL REMEDIES USED FOR THE TREATMENT OF DIABETES IN SOUTH EASTERN REGION OF NEPAL
}

\author{
Shila Singh \\ Assistant Professor, Department of Botany, Amrit Campus, Kathmandu, TU. \\ Corresponding author: singhshila41@gmail.com
}

\begin{abstract}
Traditional knowledge has become recognized worldwide to control many diseases and diabetes is also one of them. In Nepal, remote areas are the root of the indigenous knowledge of medicinal plants. The present study aimed to record traditional medicinal uses of plants to control diabetes. Several times interactions were done with the traditional healers, local knowledgeable old person and other informants like few local people and household visits. A total of 39 plant species of 35 genera belonging to 23 angiosperm families were found to be used in diabetes. About 36 types of herbal remedies were investigated from the rural inhabitants of the area. These traditional recipes include extracts, leaves, powders, flour, seeds, vegetables, fruits and herbal mixtures. Traditional knowledge systems are culturally valued and scientifically important. Strengthening and disseminating the use -value of these plants can save the money and life of poor people.
\end{abstract}

Key words: medicinal plants - diabetes - herbs - herbal remedies - tribals - Tharu community.

\section{INTRODUCTION}

Diabetes is fast gaining the status of a potential epidemic (Joshi et al., 2007 \& Kumar et al., 2013). In 2000, India (31.7 million) topped the world with the highest number of people with diabetes mellitus followed by China (20.8 million) with the United States (17.7 million) in second and third place respectively. The prevalence of diabetes is predicted to double globally from 171 million in 2000 to 366 million in 2030 with a maximum increase in India. It is predicted that by 2030 diabetes mellitus may afflict up to 79.4 million individuals in India, while China (42.3 million) and the United 
States (30.3 million) will also see significant increases in those affected by the disease (Wild et al., 2004). There were 657200 cases of diabetes in Nepal according to International diabetes federation 2017. The contribution of plant resources to health of rural people is extremely important because more than 80 percent of the population rely on traditional medicinal systems for their health care (WHO, 2002; Shrestha \& Dhillion, 2003). The important values of some plants have long been published but a large number of them remain unexplored as yet. So there is a necessity to explore their uses and to conduct pharmacognostic and pharmacological studies to ascertain their therapeutic properties (Baquar, 1989). Approximately 343 plants of the world have been tested for the blood glucose which found the lowering effect in the laboratory experiments. Of them, 158 species are claimed to be used in the Ayurved (Rahman \& Zaman, 1989). Due to changing perception of the local people and the ever increasing influence of global commercialization and socio-economic transformation, indigenous knowledge on plant resource use is constantly diminishing (Kunwar \& Adhikari, 2005). Furthermore, the indigenous knowledge on the use of lesser known plants is also rapidly declining (Kala, 2005). However, in Nepal the traditional medicinal plants that are used for the treatment of diabetes have not yet been studied in great detail. In past papers published in ethnobotany by various scientists (Manandhar, 1986; Yadav, 1999; IUCN, 2000, 2004; Dhami, 2008; Sankaranarayanan et al., 2010; Singh et al., 2012; Singh, $2015 \& 2017$ and many more scientists have also mentioned the use of few plants to treat diabetes. In fact diabetes now a day is a global problem. The present study aimed to record the ethnomedicinal uses of indigenous plants to control diabetes mellitus. The recorded traditional phytotherapy will provide the basis for clinical research in order to establish their therapeutic properties of various formulae.

\section{METHODS}

\section{Study Area}

Parsa District lies in Province 2 of Nepal located between $84^{\circ} 8^{\prime}$ to $85^{\circ} 27^{\prime} \mathrm{E}$ longitude and $27^{\circ}$ to $27^{\circ} 26^{\prime} \mathrm{N}$ latitude. This study was carried out in four villages; Gadi, Madhuban mathwal, Sonbarsa and Shanker Sharaiya of the district which is towards the south eastern part of the district. (Figure 
1 a. \& Figure 1 b.). The typical vegetation of this area is tropical forest types dominated by Shorea robusta, Acacia catechu and Dalbergia sissoo.

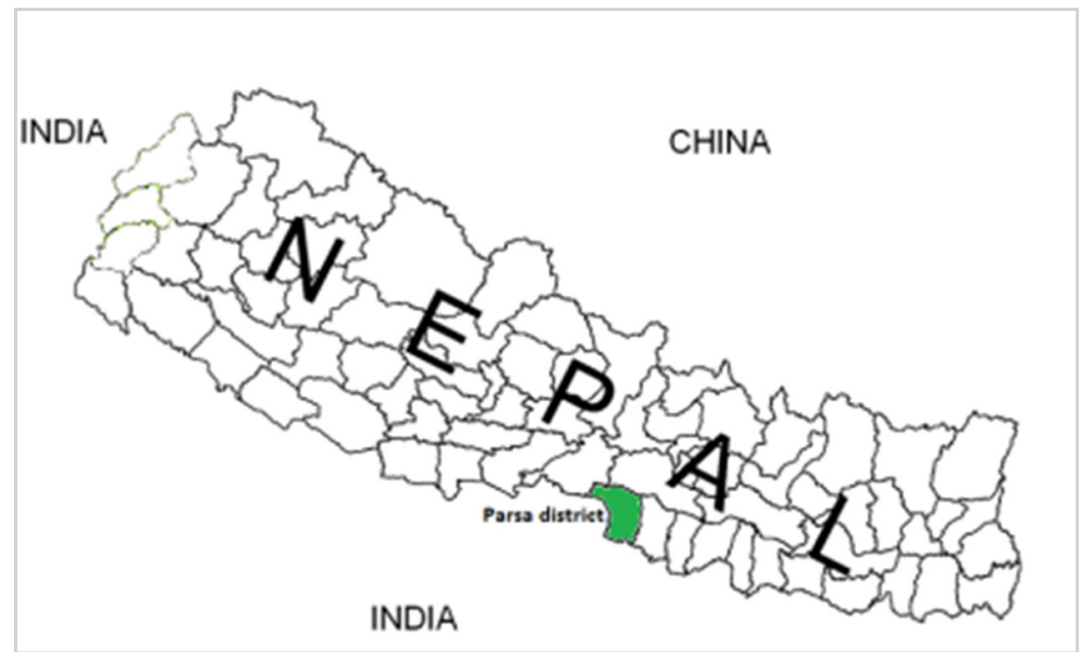

Figure 1 a. Map of study area

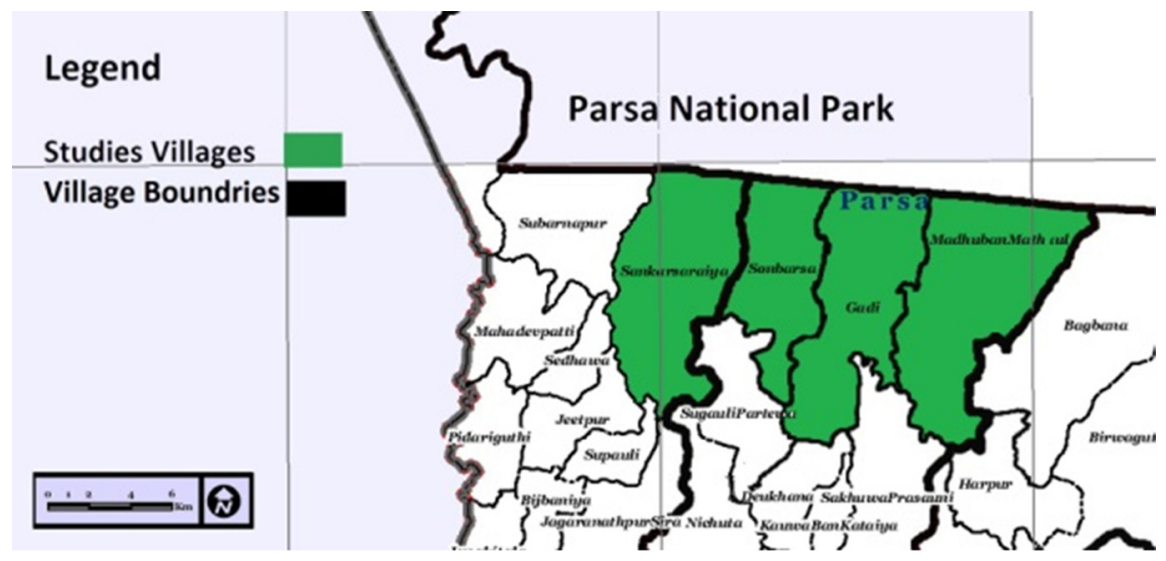

Figure 1 b. Map of studied villages

Selection of Participants, Data collection, Identification of plants and Data Analysis

A total of 50 participants (30 men and 20 women) were selected randomly from the representatives. Common participants and knowledgeable traditional medicine practitioners of the district were selected using random and purposive sampling approaches, respectively, 
following Martin (1995). Data were collected from March 2018 to February 2019. The standard data collection methods (Martin 1995 \& Cotton 1996) were followed to document traditional knowledge of the local community for treating diabetes. The techniques employed for data collection were semi -structured interviews, group discussion, field visits and observations with participants. Most data were collected from primary sources. The secondary sources include a review of literature i.e. journals, articles and books. Most of the plants were identified in the field but verified by cross -checking with the voucher specimens present in the National Herbarium and Plant Laboratory, Godavari, Lalitpur, Nepal. Common names collected during interviews were also verified with Shrestha's dictionary of Nepalese Plant Name (1998) \& IUCN report (2000). To compare the efficacy of a particular plant for diabetes, frequency of citation was also done by the participants. Preference analysis was done to analyze the most effective and most commonly used plants to control diabetes by the local inhabitants. In this exercise, 10 participants were selected randomly among the total participants.

Frequency of Citation \& Preference index was calculated by the following formulas:- (Amatya, 1996)

Frequency of citation $(\%)=\frac{\text { No. of informants who cited the species }}{\text { Total no. of informants interviewed }} \times 100$

Preference index $=\frac{\text { Preference level } \times \text { No. of respondents }}{\text { Total no. of respondents }}$

\section{RESULTS}

This study revealed 39 plant species belonging to 23 angiosperm families with 35 genera used to treat diabetes mellitus. About 36 types of herbal remedies were notified from the study area to treat diabetes. The plants species used for treating diabetes by rural inhabitants of the study area are arranged alphabetically, followed by their common name, local name, family and habit in Table 1.

The most dominant antidiabetic plant bearing family was Fabaceae having 6 species followed by Poaceae, having 4 species and Liliaceae, having 3 species (Figure 2). 
48 TRADITIONAL HERBAL REMEDIES USED FOR THE TREATMENT ...

Table 1: Name of plant species with family and habit

\begin{tabular}{|c|c|c|c|c|c|}
\hline \multicolumn{2}{|c|}{ S. N. Botanical name } & \multirow{2}{*}{$\begin{array}{l}\text { Common name } \\
\text { Vasaka }\end{array}$} & \multirow{2}{*}{$\begin{array}{l}\text { Local name } \\
\text { Asuro }\end{array}$} & \multirow{2}{*}{$\begin{array}{l}\text { Habit } \\
\text { Herb }\end{array}$} & \multirow{2}{*}{$\begin{array}{l}\text { Family } \\
\text { Acanthaceae }\end{array}$} \\
\hline 1 & Adhatoda vasica (Nees) & & & & \\
\hline 2 & Aegle marmelos (L.) Correa & Stone apple & Bel & Tree & Rutaceae \\
\hline 3 & Allium cepa $(\mathrm{L})$. & Onion & Piaz & Herb & Liliaceae \\
\hline 4 & Allium sativum (L.) & Garlic & lahsun & Herb & Liliaceae \\
\hline 5 & Aloe vera ( Mill.) & Aloe & Ghiukumari & Herb & Liliaceae \\
\hline 6 & Bixa orellana $(\mathrm{L})$. & Lipstick tree & Sindure & Tree & Euphorbiaceae \\
\hline 7 & Boerhaavia diffusa (L.) & Hog weed & Punarnava & Herb & Nyctaginaceae \\
\hline 8 & Cajanus cajan (L.) & Pigeon pea & Rahar dal & Shrub & Fabaceae \\
\hline 9 & Catharanthus roseus ( L.) & Periwinkle & Sada bahar & Herb & Apocynaceae \\
\hline 10 & Cicer arietinum (L.) & Gram & Chana & Herb & Fabaceae \\
\hline 11 & Cyperus rotundus $(\mathrm{L})$. & Nutgrass & Motha & Herb & Cyperaceae \\
\hline 12 & Daucus carrota (L.) & Carrot & Gajar & Herb & Apiaceae \\
\hline 13 & Delonix regia (Hook.) Raf. & Flame tree & Gulmohar & Tree & Fabaceae \\
\hline 14 & Dillenia pentagyna (Roxb.) & Kamada & Tantari & Tree & Dilleniaceae \\
\hline 15 & Ficus bengalensis (L.) & Banyan & Bar & Tree & Moraceae \\
\hline 16 & Ficus racemesa (L.) & Fig & Gular & Tree & Moraceae \\
\hline 17 & Hibiscus rosa- sinensis (L.) & China rose & orhul & Shrub & Malvaceae \\
\hline 18 & Hordeum vulgare (L.) & Barley & Jau & Herb & Poaceae \\
\hline 19 & Melia azedarach(L.) & China berry & Bakaino & Tree & Meliaceae \\
\hline 20 & Momardica charantia (L.) & Bitter gourd & Karela & Climber & Cucurbitaceae \\
\hline 21 & Murraya koenigii (L.) & Curry leaf & Mitho nim & Shrub & Rutaceae \\
\hline 22 & Ocimum album (L). & White basil & Ban Tulsi & Herb & Lamiaceae \\
\hline 23 & Ocimum sanctum (L.) & Holy basil & Tulsi & Herb & Lamiaceae \\
\hline 24 & Oryza sativa (L.) & Rice & Chawal & Herb & Poaceae \\
\hline 25 & Oxalis corniculata (L.) & Indian sorrel & Chari amilo & Herb & Oxalidaceae \\
\hline 26 & Phyllanthus emblica (L.) & Goose berry & Amla & Tree & Euphorbiaceae \\
\hline 27 & Psidium guajava $(\mathrm{L})$. & Guava & Amba & Tree & Myrtaceae \\
\hline 28 & Rosa alba (L.) & Rose & Gulab & Shrub & Rosaceae \\
\hline 29 & Scoparia dulsis (L.) & Goat weed & Mithajhar & Herb & scrophulariaceae \\
\hline 30 & Solanum nigrum ( L). & Black nightshade & Kalo bihi & Herb & Solanaceae \\
\hline 31 & Syzygium cuminii (Skeels) & Black plum & Jamoon & Tree & Myrtaceae \\
\hline 32 & Tinospora cordifolia (L.) & Guduchi & Gurju & Twinner & Menispermaceae \\
\hline 33 & Trigonella foenum-graecum (L.) & Fennugreek & Methi & Herb & Fabaceae \\
\hline 34 & Triticum aestivum (L.) & Wheat & Gahun & Herb & Poaceae \\
\hline 35 & Vigna mungo (Burm. f.) & Green gram & Mung & Herb & Fabaceae \\
\hline 36 & Vigna sinensis (Burm. f.) & Cow bean & Bori & Twinner & Fabaceae \\
\hline 37 & Withania somnifera (L.) & Wintercherry & Aswagandha & Shrub & Solanaceae \\
\hline 38 & Zea mays (L.) & Maize & Makai & Herb & Poaceae \\
\hline 39 & Zizyphus jujube (Mill.) & Chinee tree & Bayar & Tree & Rhamnaceae \\
\hline
\end{tabular}

Source: Field survey, 2018 \& IUCN, 2000 


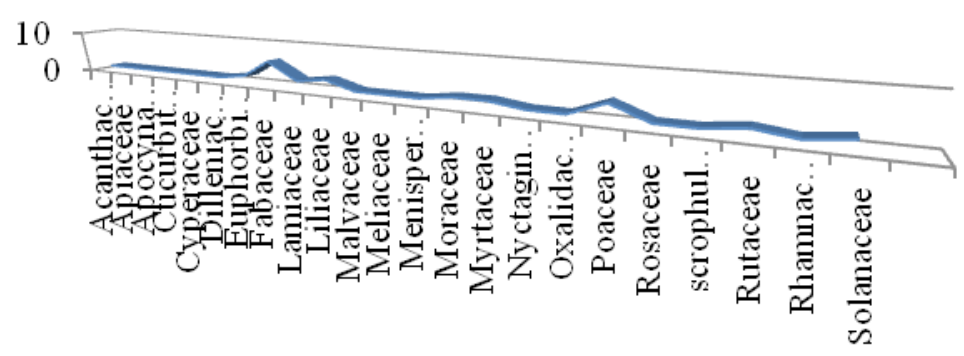

Figure 2: Family wise analysis of the studied plants

Different parts of the plants like, Leaves, seeds, fruits, shoot, bulb, bark, wood, stem and root are used as medicines. But, the most commonly used part of the plants was leaf (Table 2).

Table 2: List of plant parts used for making crude drug

\begin{tabular}{cccc}
\hline S. $\mathbf{~}$. & Plant parts & No of species used & \% of richness \\
\hline 1 & Leaf & 12 & 31 \\
2 & Seed & 10 & 26 \\
3 & Fruit & 7 & 18 \\
4 & Shoot & 3 & 8 \\
5 & Bulb & 2 & 5 \\
6 & Bark & 2 & 5 \\
7 & Wood & 1 & 2 \\
8 & Stem & 1 & 2 \\
9 & Root & 1 & 2 \\
\hline
\end{tabular}

Source: Field survey, 2018

The different parts of the plants used as medicines in different ways which include filtrate, raw leaves, powder, flour, seeds, vegetables, fruits and herbal mixture. Filtrates and powder are a common mode of medicines preparation (Table 3).

Depending upon the habit, among total studied plants; 20 plants $(51 \%)$ are herbs, 11 plants (28\%) are trees, 5 plants (13\%) are shrubs, 2 plants $(5 \%)$ are twinners and 1 plant (3\%) is a climber (Figure 3). 
Table 3: Mode of preparation of medicines

\begin{tabular}{cccc}
\hline S.N. & Types of medicines & No of species used & \% of richness \\
1 & Filtrate & 12 & 34 \\
2 & Powder & 7 & 20 \\
3 & Vegetable & 4 & 11 \\
4 & Leaf & 4 & 11 \\
5 & Fruit & 3 & 9 \\
6 & Seed & 2 & 6 \\
7 & Latex & 2 & 3 \\
8 & Bread & 1 & 3 \\
9 & Herbal mixture & 1 & 3 \\
\hline
\end{tabular}

Source: Field survey, 2018

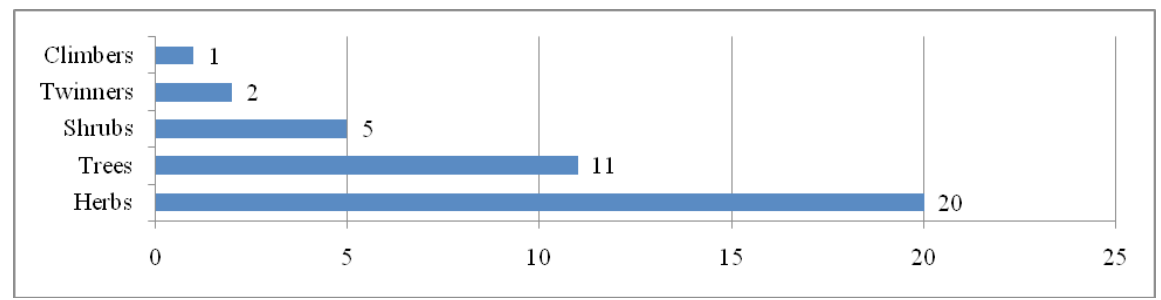

Figure 3: Plant species based upon habit used for diabetes

The result showed that the preference index of Syzygium cumini is highest followed by Catharanthus roseus in the second position and Tinospora cordifolia in third position (Table. 4).

Table 4: Preference Analysis of most preferred plants for diabetes

\begin{tabular}{llllllll}
\hline S.N. & \multicolumn{1}{c}{ Plant Species } & \multicolumn{4}{c}{ No. of Respondents } & Preference & Rating \\
& & per Preference level & Index & \\
& & $\mathbf{1}$ & $\mathbf{2}$ & $\mathbf{3}$ & & \\
\hline 1 & Syzygium cumini & 4 & 5 & 1 & 1.7 & I \\
2 & Catharanthus roseus & 4 & 4 & 2 & 1.8 & II \\
3 & Tinospora cordifolia & 4 & 0 & 5 & 1.9 & III \\
4 & Trigonella foenum graecum & 3 & 4 & 3 & 2.0 & IV \\
5 & Scoparia dulsis & 2 & 3 & 4 & 2.2 & V \\
\hline
\end{tabular}

Source: Field survey, 2018

The result of this study showed that plants used for treating diabetes were in nine different categories viz., antidiabetic filtrate, antidiabetic leaves, 
antidiabetic powder, antidiabetic bread, antidiabetic seeds, antidiabetic latex, antidiabetic herbs/vegetables, antidiabetic fruits and antidiabetic herbal mixture. In antidiabetic filtrate category; about $10 \mathrm{ml}$ of few fresh leaves filtrate of Adhatoda vasica is used thrice a day (Citation \%23), the pulp of fresh leaves (2") of Aloe vera is taken either directly or mixing with water (Citation \%25), hot decoction of dried leaves of Psidium guajava is used (Citation \% 45), the filtrate of 4-5 leaves of Aegle marmelos is taken in the morning in empty stomach (Citation \% 60), 3-4 leaves of Tinospora cordifolia are ground with water and filtrate is taken in morning in empty stomach (Citation \% 73), filtrate of 4-5 leaves of Hibiscus rosasinensis is taken in the early morning ( Citation \% 40 ), one table spoon of the juice of bulb of Allium cepa is taken thrice a day (Citation \% 20 ), Water kept overnight in the tumbler made by the heart wood of Pterocarpus marsupium is taken in the morning to cure diabetes ( Citation \% 35) and decoction of half table spoon bark powder of Dillenia pentagyna is taken to cure diabetes (Citation \% 25).

In antidiabetic leaves category; 4-5 fresh leaves of Ziziphus jujube are chewed daily to lower blood glucose level (Citation \% 36), 2-3 Fresh leaves of Psidium guajava are masticated and taken twice a day with glass of water (Citation \% 35 ), 4-5 fresh leaves of Scoparia dulcis are chewed daily (Citation \% 67).

In antidiabetic powder category; 1 tea spoon dry leaf powder of Delonix regia is taken in the morning (Citation \% 25). 1 gm dry leaves powder of Ocimum sanctum is given with water twice a day (Citation \% 30), 1 table spoon of dry fruit powder of Momordica charantia is taken twice a day to lower blood glucose level (Citation \% 45), about half tea spoon fruit powder of Melia azedarach is given with water before breakfast daily for a month (Citation \% 50), 1 table spoon of seed powder of Syzygium cumini is used twice a day with water before meal (Citation \% 80 ), seeds of Hordeum vulgare and Cicer arietinum in the ratio of 3:1 are roasted and ground and a half table spoon of this powder is taken with water thrice a day to control blood glucose level (Citation \% 35), one tea spoon bark powder of Ficus racemosa is prescribed (Citation \% 67 ) and about half teaspoon stem powder of Tinospora cordifolia is taken with water twice a day before meal (Citation \% 75).

In antidiabetic bread category; equal amount of Cicer arietinum (Seeds), Daucus carrota (Dried root), Hordeum vulgare (Seeds), Oryza sativa (Seeds), Triticum aestivum (Seeds) and Zea mays (yellow variety) are ground. The bread is cooked from this mixed flour and taken as breakfast 
with fresh butter of cow for 2-month (Citation \% 45). This remedy is used as a dietary supplement to control diabetes.

In antidiabetic seeds category; 1 table spoon soaked seeds of Trigonella foenum-graecum are given daily before meal once or twice a day (Citation \% 65) and 1 tea spoon seeds of Withania somnifera are soaked in water in the night and given in the morning before breakfast to the patient (Citation \% 45).

In antidiabetic latex category; half tea spoon sap obtained from fruit of Bixa orellana is used to control blood glucose level (Citation \% 40 ) and 1 table spoon latex obtained from the young branches of Ficus benghalensis is taken with honey (Citation \% 35).

In antidiabetic herbs/vegetables category; the fresh aerial parts of Solanum nigrum are cooked as a vegetable (Citation \% 25), aerial parts of Boerhaavia diffusa are cooked as a vegetable (Citation \% 20), the pulse obtained from the seeds of Cajanus cajan \& Vigna mungo is recommended (Citation \% 27) and three or four bulblets of Allium sativum are taken in the morning (Citation \% 30).

As antidiabetic fruits; immature pods of Vigna sinensis are used (Citation \% 15), fresh fruits of Syzygium cuminii are taken (Citation \% 50) and fresh fruits of Phyllathus emblica are eaten to control blood glucose level (Citation \% 45).

As antidiabetic herbal mixture; powder of seeds of Syzygium cumini \& Momordica charantia (2 parts), Cyperus rotundus \& Rosa alba (1 part) is made. This mixture is taken before meal for lowering blood glucose by the inhabitants of the study area (Citation \% 25).

\section{DISCUSSION}

The old people of the study area treat diabetes through these traditional herbal remedies. They believe that traditional medicines are the better and permanent cure for their diseases. So, the indigenous knowledge continues to provide the building blocks for the development in rural communities (Rahman \& Zaman, 1989). Out of total reported plants few plants like ; Syzygium cumini, Catharanthus roseus, Tinospora cordifolia, Aegle marmelos, Momordica charantia, Ficus racemosa, Trigonella foenumgraecum, Scoparia dulsis and Melia azedarach were highly preferred by the Tharu people on the basis of citation \%. Similarly, preference index analysis showed that Syzygium cumini got the highest position followed by, Catharanthus roseus and Tinospora cordifolia in second and third position 
for treating diabetes. Citation percentage of these three plants was also high. There were many overlapping of the use of plant species for same disease in the studied villages, for example, in the village Madhuban mathwal fruit of Momordica charantia was used as powder but in Gadi it was used as fresh fruit filtrate. But in some cases, the use-value in the studied villages was uncommon, for example, in Gadi and Sonbarsa, leaf of Adhatoda vesica was used to treat fever and asthma but in Shankar sharaiya it was used in diabetes. In Madhuban mathwal Aegle marmelos was used in fever and dysentery but in Gadi and Shankar shraiya it was used in diabetes. This study also disseminated the common use-value of these studied plants among traditional healers of all studied villages. Almost all studied plants are available in an all villages except Withania somnifera which was found only in village Gadi. In the study area, herbs are the primary source of herbal remedies, followed by trees, most likely because herbs are more abundant. This is perhaps because herbs leaves are the most frequently utilized part of the plant to treat diabetes. They also have a faster growth rate and may possess bioactive secondary metabolites concerning to the environment (Paul et al., 2015). The uses of plants are well known among the traditional healers of the all studied villages. These healers are considered to be very effective in treating diseases. Medicinal plant resources are an important component of biodiversity with an important source for local livelihood as well as they have cultural significance. Therefore, the conservation of medicinal plants is not only vital for the livelihood of local people but also it has immense cultural significance to them. During the study, it was found that the traditional herbal remedies were more adaptable and acceptable from past to present in this area. Due to widespread use, folk herbal remedies appear to be not only a case of preference but also of a situation without choices due to lack of modern medical facilities. Such a system of medical treatment on which the majority of the population has been relying upon for generations with considerable success should not be overlooked for further medical investigation. This case is valid for those plants which have not been looked at for medical research, although the same has been in use by local inhabitants over hundreds of years.

\section{Identification of new claims and reliability of reported claims}

The reported uses of various medicinal plants of the present study were compared with the previously published papers in Nepal and India; Burlakoti et al. (2008); Dhami (2008); Joshi (2008); Gurung et al. (2008); Sankaranarayanan et al. (2010) and Singh et al. (2012);. The present study identified many new and different way of uses of these studied plants to 
treat diabetes which were not mentioned in the previous papers except about Momardica charantia, Murraya koenigii and Trigonella foenum graecum.

\section{CONCLUSIONS}

In present scenario diabetes is a global problem and every year a considerable amount of foreign exchange is involved in the import of antidiabetic drugs. In present study many plants were notified to control diabetes. But few plants like, Syzygium cumini, Catharanthus roseus and Tinospora cordifolia are highly preferred to control diabetes. So, it is strongly recommended to carryout phytochemical and clinical research work on these plants and also reported plant species of this study to prove and substantiate the traditional herbal therapies of the rural people. These plants should be studied for their active compounds responsible for the hypoglycemic activities

\section{ACKNOWLEDGEMENT}

The author extends sincere gratitude to the ethnic community and local people of the studied villages of the Parsa district for their generous cooperation during the field study. The D.F.O., Forest officer of the district are acknowledged for facilitating the field trips. Similarly, local traditional healers are also acknowledged for providing valuable information.

\section{REFERENCES}

Amatya, G. (1996). Ethnomedicinal uses of plants of Bara district, Nepal. In: P. K. Jha, G.P.S. Ghimire, S. B. Karmacharya, S. R. Baral and P. Lacoul (eds.), Environment and Biodiversity: In context to South Asia, pp. 126-163. RONAST, Nepal.

Burlakoti, C. \& Kunwar, R. M. (2008). Folk herbal medicines of Mahakali waterhheds area, Nepal, In: Jha, P. K., Karmacharya. S. B., Chhetri, M. K., Thapa, C. B. \& Shrestha, B. B.(eds.), Medicinal plants in Nepal: an Anthology of Contemporary Research, pp. 188-194, ECOS: Nepal.

Baquar, S. R. (1989). Medicinal and poisonous plants of Pakistan. Printas, Karachi, Pakistan. pp. 95-96.

Cotton, M. C. (1996). Ethnobotany, principles and applications, John Wiley \& Sons, Chichister, UK. pp. 20- 125.

Gurung, J. L., Rajbhandary, S. \& Ranjitkar, S. (2008). Indigenous knowledge on medicinal plants in mid hills of Nepal: A case study of sikles area of Kaski District, In: Jha, P. K., Karmacharya. S. B., Chhetri, M. K., Thapa, C. B. \& Shrestha, B. B.(eds.), Medicinal 
plants in Nepal: An anthology of contemporary research, pp.153164, ECOS: Nepal.

Dhami, N. (2008). Ethnomedicinal uses of plants in western terai of Nepal, In: Jha, P. K., Karmacharya. S. B., Chhetri, M. K., Thapa \& C. B., Shrestha, B. B.(eds.), Medicinal plants in Nepal: an anthology of contemporary research, pp.164-176 ECOS: Nepal.

IUCN. (2000). National register of medicinal plants. IUCN- The world conservation union, Kathmandu, Nepal.

IUCN. (2004). National register of medicinal plants. IUCN- The world conservation union, Kathmandu, Nepal.

Joshi, K. R. (2008). Ethnomedicinal uses of plants: A case study of Sharmoli VDC, Darchula District, Nepal, In: Jha, P. K., Karmacharya. S. B., Chhetri, M. K., Thapa, C. B. \& Shrestha, B. B.(eds.), Medicinal plants in Nepal: an anthology of contemporary research, pp.177186 ECOS: Nepal.

Joshi, S. R. \& Parikh, R. M. (2007). India - diabetes capital of the world: now heading towards hypertension. Journal of Association of Physician of India, 55: 323-324.

Kala, C. P. (2005). Current status of medicinal plants used by traditional vaidyas in Uttaranchal, India. Ethnobotany Research and Applications, 3:267-278.

Kunwar, R.M. \& Adhikari, N. (2005). Ethnomedicine of Dolpa district, Nepal: the plants, their vernacular names and uses. Lyonia, 8(1): 43-49.

Kumar, A., Goel, M. K., Jain, R. B., Khanna, P. \& Chaudhary, V. (2013). India towards diabetes control: Key issues, Australasian Med. J. 6(10): 524-531. https://doi: 10.4066/AMJ.2013.1791

Manandhar, N. P. (1986). A contribution to the ethnobotany of Mooshar tribes of Dhanusha district,Nepal. Journal of Natural History Museum, 10 (1-4): 53-64.

Martin, J. G. (1995). Ethnobotany: A method manual. People and conservation manual, Champman and Hall, London, UK. pp. 1-25.

Paul, C. C., Chiedozie, O. I. \& Ferdinand, N. M. (2015). Bioactive principles from medicinal plants. Research Journal of phytochemistry. 9(3): 88-115. https://doi: 10.3923/rjphyto.2015.88.115

Rahman, A.U. \& Zaman, K. (1989). Medicinal plants with hypoglycemic activity, Journal Ethnopharmacol. 26: 1-55. 
Sankaranarayanan, S., Bama, P., Ramchandran, J. B. \& Sathya, S. (2010). Ethnobotanical study of medicinal plants used by traditional users in Villupuram district of Tamilnadu, India. Journal of Medicinal Plants Research, 12: 1089-1101.

Shrestha, K. K. (1998). Dictionary of Nepalese plant name, Mandala Book Point, Nepal. pp. 205-207.

Shrestha, P.M., \& Dhillion, S.S. (2003). Medicinal plants diversity and use in the highlands of Dolakha district, Nepal. Journal Ethnopharmacology, 86: 81-96.

Singh, A. G., Kumar, A. \& Tiwari, D. D. (2012). An ethnobotanical survey of medicinal plants used in Terai forest of western Nepal. Journal of Ethnobiology and Ethnomedicine, 19: 8-19. doi: https://doi. org/10.1186/1746-4269-8-19

Singh, S. (2015). Ethnobotanical study of some wild herb species Parsa District Forest of Nepal, Journal of Pharmacognosy and phytochemistry, 4 (1): 32-40.

Singh, S. (2015). Ethnobotanical study of indogenous knowledge on some wild plants in Parsa district, Nepal. Journal of Natural History Museum, 29: 103-121. https://doi.org/10.3126/jnhm.v29i0.19042

Singh, S. (2017). Ethnobotanical study of wild plants of Parsa District, Nepal, J. Ecoprint, 24: 1-12. https://doi.org/10.3126/eco.v24i0.20641

Stainton, A. (1988). Flower of the Himalaya, a supplement. Oxford University Press. New Delhi, India.

Wild, S., Roglic, G., Green, A., Sicree, R. \& King, H. (2004). Global prevalence of diabetes-estimates for the year 2000 and projections for 2030. J. Diabetes Care. 27(3): 1047-1053.

WHO. (2002). WHO monographs on selected medicinal plants. Volume 2. Geneva, World Health Organization.

Yadav,R.K.P. (1999). Medicinal plants and traditional practice in eastern part of Parsa district, Nepal, Proceeding of the $3^{\text {rd }}$ National Conference on Science and Technology. RONAST, Kathmandu, pp.1421-1426. 